Journal of Islamic Economics Perspectives, Volume 3. Issue l (2021)

\title{
INFLUENCE OF WORK EXPERIENCE, MOTIVATION AND COMPETENCE ON MEE MACAU SURABAYA
}

\author{
Ester Julita Sari Ritonga, Rismawati Sitepu, Nur Hidayat, Marten Zebua, Riyan \\ Sisiawan P.
}

\begin{abstract}
The purpose of this study was to determine the effect of work experience, motivation and competence on employee performance at Mee Macau Surabaya. This type of research is quantitative with secondary data. The sample in this study were 40 employees at Mee Macau Surabaya. The sampling technique used a population sample / saturated sample. The method of collecting data using a questionnaire. Data analysis using multiple linear regression analysis. The results showed that there was a significant influence between work experience, motivation and competence on employee performance both partially and simultaneously. And the calculation of $\mathrm{F}$ is known that Fcount $=51.784>\mathrm{F}$ table 2.87 with a significance of $0.000<$ alpha 0.05 . Partially it is known that the variables work experience, motivation and competence have a significant effect on employee performance. After the $t$ test (partial) work experience variable (X1) has t count 2.246>t table 2.02108 and from the motivation variable $(\mathrm{x} 2) \mathrm{t}$ count $=12.342>2.02108$ and from the competency variable $(\mathrm{X} 3)$ $\mathrm{t}$ count $=2.058>\mathrm{t}$ table 2,0218 .
\end{abstract}

Keywords: Work Experience, Motivation, Competence, Performance.

\section{INTRODUCTION}

In the current era of globalization in Indonesia, competition is very fierce in all fields, both in the fields of economy and science and technology. An economy that is never separated from the words of everyday life for the sake of the smooth running of the country. Many factors are involved in the field of day-to-day economics and their scope is very broad when described and linked, one of which is about Human Resources (Human Resources). Human Resources are very important in the smooth running of a company, because it will affect the output with the presence of HR. Employees themselves have the meaning of an important asset that has a very big influence on the success of the company or it can also be interpreted as a person who provides services to a company or organization that requires labor, from which the employee will get remuneration in the form of salary and other compensation, while human resources are influenced by several factors in working to become qualified human resources. 
But the company must also be able to build and improve performance in the work environment so that it can produce good output. To achieve this, all companies have a role in building and creating quality employee performance, then there are several things that become factors to improve employee performance. Employee performance is influenced by several factors, namely compensation, employee training, work environment, work culture, leadership, motivation, discipline and job satisfaction.

Mee Macau takes advantage of the opportunities that exist by establishing a place to eat that can attract the attention of visitors. To win the competition or just survive in today's competition, a company must be able to have a strong vision and mission in order to achieve the company's goals as effectively and efficiently as possible. This has an impact on the services provided by the hotel to visitors and the community as needed. Serdamayanti (2011: 260) Employees state that performance is a translation of the word performance which means the work of an employee or worker, a management process where the work results must have concrete evidence that can also be measured. Performance is the work result in quality and quantity achieved by an employee in carrying out a task. In the corporate world, companies need high performance. At the same time, employees provide feedback / work results. Performance is influenced by the ability factor (ability) and the motivation factor. Work experience, motivation and competence affect employee performance results. Work experience is the process of forming knowledge or skills about the method of a job because of the employee's involvement in the implementation of tasks. Work experience can be obtained through experience, practice or can be direct. According to <Marwansyah in Warianti (2015) work experience is the knowledge, skills and abilities that employees have to carry out responsibilities in previous jobs. According to Merihot (Mariani 2015) motivation is the factors that direct and encourage behavior, a person's desire to carry out an activity which is expressed in the form of hard effort. With motivation, someone can do something enthusiastically. Motivation is influenced by internal and external factors that come from employees. Competence is an adequate skill to do an assignment / as having the skills and abilities required by Suparno (2012: 27). Work experience, motivation and competence have an influence on employee performance at Mee Macau Surabaya. This research was conducted at Mee Macau Surabaya. This research was conducted to examine the influence of work experience, motivation and competence on employee performance, it is hoped that what the company has done is useful for employees and can improve the quality of employee performance.

\section{LITERATURE REVIEW}

\section{Performance}


According to Fahmi (2012: 2) performance is the result obtained by an organization that is positive oriented and non-profit oriented which is generated over a period of time. According to Bastian (2010: 2), performance is a description of the level of achievement of the implementation of an activity / program / policy in realizing the goals, objectives, mission and vision of the organization as stated in the formulation of an organization's strategic planning. Performance is influenced by the ability factor (ability) and the motivation factor. From the several opinions that have been explained, it can be taken the notion that performance is the work achieved by an employee in an organization. In the corporate world, companies need high performance. At the same time, employees need feedback or the results of their work as a guide for their behavior in the masses to come. Performance is closely related to an opinion that in order to find out the performance results achieved in a company, the first thing the leader must do is carry out a job appraisal. Job appraisal is very useful for determining job training needs appropriately, assigning appropriate responsibilities to employees so that they can carry out a better job in the future and as a basis for determining policies in promotion or determination of rewards. Job appraisal refers to a formal and structured system used to measure, assess and influence job-related attributes.

\section{Work Experience}

According to Marwansyah (waraianti 2015) work experience is a knowledge, skills and abilities that employees have to carry out responsibilities in their previous work. People who are experienced at work have better work abilities than people who have just entered the world of work, because that person has learned from the activities and problems that arise in their work. With work experience, there has been a process of enhancing knowledge and skills and attitudes in a person, so that it can support self-development with existing changes. Work experience can be obtained through experience, practice or it can be direct. As from reading besides that past performance at similar work can be the best indicator of future arrivals. The driving factors for work experience are personal background, talents and interests, analytical and manipulative attitudes and needs, skills, skills and abilities.

\section{Motivation}

Motivation According to Merihot (maraiani: 2015) motivation is the factors that state and encourage a person's behavior / desire to carry out an activity that is expressed in the form of hard effort. According to Robbin and Judge (2013), motivation is a process carried out by individuals who seek to achieve goals, including 3 important elements, namely intensity, direction and persistence. Every action is always due to motivation. The emergence of motivation is because a person feels a certain need and because of this the 
action is directed at achieving certain goals. When the goal has been achieved, you will feel satisfied. Behavior that has given satisfaction to a need tends to be repeated, so that it becomes stronger and more stable. Human needs are not merely things that are desired to fulfill primary demands, such as food, clothing and security demands. There are two kinds of human needs, namely needs that are based on and needs or desires that are not based. Every activity that a person does is inseparable from various motives and attitudes, which encourage someone to do a series of actions called activities. Motive Based on the definition of motivation that has been described, conclusions can be drawn about the notion of motivation, which is a motivation / reason that becomes the basis for one's enthusiasm to do something to achieve certain goals. Motivation is influenced by internal and external factors, namely internal and environmental factors.

\section{Competence}

According to Suparno (2012: 27) Competence is an adequate ability to do a task / as having the skills and abilities that are indicated. According to Pramudyo (2010: 32) competence is a set of knowledge, the behavior that a person must have in carrying out his professional duties. In the context of operations, these competencies enable human resources to explore the potential of other resources owned by the company, able to make them more effective and efficient. the production process within the company as well as being able to produce products that satisfy the needs and desires of consumers. Managerial competence must be created especially through effective and efficient management of resources. The management in question is based on three principles. Based on the definition

of competency that has been described, conclusions can be drawn about the definition of competence, namely the ability that a person has to carry out a task. Competence is also defined as ability, then it means knowledge of understanding the purpose of work, knowledge of carrying out a proper and good job.

\section{PREVIOUS RESEARCH}

There are several previous studies that can be used as references for the authors relating to this research, among others. In writing that Bella Puspita Sari has done, 2018 with the title Influence of Competence, Motivation and Work Discipline, on the Performance of PT BATANG BUMI MANDIRI employees. This research aims to determine the effect of competence, motivation and work discipline on employees of PT BATANG BUMI MANDIRI. There are four variables in this study, namely Competence (X1), Motivation (X2), Competence (X3) and Employee Performance (Y). Based on the results of the research that has been done, it can be concluded that there is a significant influence on employees. Competence factors have a significant effect as well as motivation and discipline factors. Then the second research that has been researched by Latifah Isnaini 
Fauzi, 2018 with the title The Effect of Work Motivation and Work Experience on Employee Performance of PT ADI SATRIA. This study aims to determine the effect of motivation and work experience. There are three variables in this study, namely Motivation (X1), Work Experience (X2) and Employee Performance (Y). Based on the results of research that has been done it can be concluded that a significant influence on employees, motivation factors have a positive and significant effect on employee performance and work experience factors have a positive and significant effect on employee performance.

\section{RESEARCH METHODS}

This research uses quantitative analysis, using a population sample / saturated sample. The method of collecting data using a questionnaire. Data analysis used descriptive analysis and multiple linear regression.

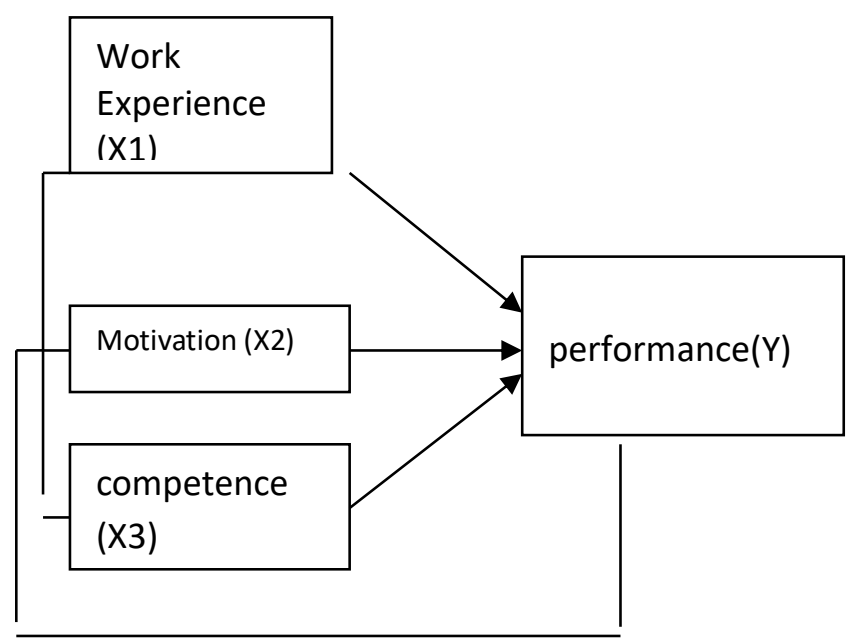

\section{Hypotesis}

H1: Work experience has a significant positive effect on employee performance

H2: Motivation has a positive effect significant to employee performance

H3: Competence has a significant positive effect on employee performance

H4: Work experience, motivation and competence have a significant positive effect on employee performance

This type of research used in this research is quantitative with secondary data. This research was conducted at Mee Macau Surabaya with the number of samples in this study were 40 people. The data collection method in this study is to use a questionnaire technique, 
using a saturated sample. The data analysis technique used in this study was multiple linear regression statistical analysis.

Research Respondent Character

Table 4.1

Base on age

\begin{tabular}{|l|c|c|c|}
\hline \multicolumn{1}{|c|}{ No } & Age & Total & Persentage(\%) \\
\hline 1 & $21-30$ & 23 & $57.5 \%$ \\
\hline 2 & $31-40$ & 14 & $35 \%$ \\
\hline 3 & $41-50$ & 3 & $7.5 \%$ \\
\hline \multicolumn{2}{|c|}{ Total } & 40 & $100 \%$ \\
\hline
\end{tabular}

source: primary data (2019)

Based on age, it can be seen that the number of employees in the company aged 20-30 years is 23 people with a total percentage of 57.5\%, 14 people aged 31-40 years with a total percentage of $35 \%$, and 3 people aged $41-50$ years with a total percentage of $7.5 \%$. It can be concluded that Mee Macau Surabaya employees are mostly 21-30 years old.

Tabel 4.2

Respondent character by gender

\begin{tabular}{|c|c|c|c|}
\hline No & gender & Total & Persentage (\%) \\
\hline 1 & Male & 13 & $32.5 \%$ \\
\hline 2 & Female & 27 & $67.5 \%$ \\
\hline \multicolumn{2}{|c|}{ Total } & 40 & $100 \%$ \\
\hline
\end{tabular}

Sumber: primary data (2019)

Based on the results of existing respondent data, the gender characteristics of the respondents indicated that 13 respondents were male with a total percentage of $32.5 \%$, and 27 people were female with a total percentage of $67.4 \%$. It can be concluded that Mee Macau Surabaya employees have more female employees than male employees. 


\section{Table4.3}

respondent characteristic by education level

\begin{tabular}{|c|c|c|c|}
\hline No & Education level & total & Persentage (\%) \\
\hline 1 & Graduate & 13 & $32.5 \%$ \\
\hline 2 & Bhacelor & 2 & $5 \%$ \\
\hline 3 & High School & 25 & $62.5 \%$ \\
\hline \multicolumn{2}{|c|}{ Total } & 40 & $100 \%$ \\
\hline
\end{tabular}

Sumber: primary data (2019)

Based on the results of existing respondent data, the characteristics of the respondent's latest education indicate that the level of education for undergraduate level 1 and 2 is 13 people with a total percentage of $32.5 \%$, diploma as many as 2 people with a total percentage of $5 \%$, and SMA / SMK as many as 25 people with a total percentage $62.5 \%$. It can be concluded that the education level of employees, there are more SMA / SMK graduates than other education levels in the table above.

\section{Test Validity}

\section{ANALYSIS DATA}

The validity test was carried out by looking at the rcount and rtabel of each statement item through data processing carried out by the SPSS program. Each statement item is said to be valid if $r$ count $>r$ table. The results of the validity test in this study of each statement item are as follows:

a. Validity test of The work experience variable $\left(\mathrm{X}_{1}\right)$

Tabel 4.4

Validity test by work experience $\left(\mathrm{X}_{1}\right)$

\begin{tabular}{|c|c|c|c|}
\hline Question & r-count & r-tabel & statement \\
\hline $\mathrm{X}_{1.1}$ & 0.686 & 0.3120 & Valid \\
\hline $\mathrm{X}_{1.2}$ & 0.617 & 0.3120 & Valid \\
\hline $\mathrm{X}_{1.3}$ & 0.772 & 0.3120 & Valid \\
\hline $\mathrm{X}_{1.4}$ & 0.713 & 0.3120 & Valid \\
\hline $\mathrm{X}_{1.5}$ & 0.771 & 0.3120 & Valid \\
\hline
\end{tabular}


Source: primary data SPSS (2019)

The work experience variable consists of 5 statement items. The correlation of each statement item has a calculated $r$ value greater than $r$ table so that based on the validity test it shows that all statement items on the work experience variable are declared valid and can be used as a research instrument

b. Test Validity Motivation $\left(\mathrm{X}_{2}\right)$

Based on the results of data processing, the validity test of the Motivation variable (X2) can be seen in the table below:

Tabel 4.5

validity test of the Motivation variable $\left(\mathbf{X}_{2}\right)$

\begin{tabular}{|c|c|c|c|}
\hline Quetions & r-count & r-table & Statement \\
\hline $\mathrm{X}_{2.1}$ & 0.767 & 0.3120 & Valid \\
\hline $\mathrm{X}_{2.2}$ & 0.710 & 0.3120 & Valid \\
\hline $\mathrm{X}_{2.3}$ & 0.595 & 0.3120 & Valid \\
\hline $\mathrm{X}_{2.4}$ & 0.609 & 0.3120 & Valid \\
\hline $\mathrm{X}_{2.5}$ & 0.529 & 0.3120 & Valid \\
\hline
\end{tabular}

sourcer: primary data by SPSS (2019)

The motivation variable consists of 5 statement items. The correlation of each statement item has a value of $r$ count greater than $r$-table, so based on the validity test it shows that all statement items on the motivation variable are declared valid and can be used as a research instrument.

c. Validity Test of Competence $\left(\mathrm{X}_{3}\right)$

Based on the results of data processing, the competency variable validity test (X3) can be seen in the table below

Tabel 4.6

Validity Test of Competence (X3)

\begin{tabular}{|l|c|c|c|}
\hline Questions & r-count & r-table & Statement \\
\hline
\end{tabular}




\begin{tabular}{|c|c|c|c|}
\hline $\mathrm{X}_{3.1}$ & 0.592 & 0.3120 & Valid \\
\hline $\mathrm{X}_{3.2}$ & 0.674 & 0.3120 & Valid \\
\hline $\mathrm{X}_{3} .3$ & 0.680 & 0.3120 & Valid \\
\hline $\mathrm{X}_{3} .4$ & 0.473 & 0.3120 & Valid \\
\hline $\mathrm{X}_{3.5}$ & 0.732 & 0.3120 & Valid \\
\hline
\end{tabular}

source: primary data by SPSS 16 (2019)

The competency variable consists of 5 statement items. The correlation of each statement item has a value of $r$ count greater than $r$-table, so based on the validity test it shows that all statement items on the competency variable are declared valid and can be used as a research instrument.

d. Validity Test of Performance Variable (Y)

Tabel 4.7

Validity Test of Performance Variabel (Y)

\begin{tabular}{|c|c|c|c|}
\hline Questions & r-count & r-table & Statemnet \\
\hline Y.1 & 0.361 & 0.3120 & Valid \\
\hline Y.2 & 0.678 & 0.3120 & Valid \\
\hline Y.3 & 0.772 & 0.3120 & Valid \\
\hline Y.4 & 0.663 & 0.3120 & Valid \\
\hline Y.5 & 0.686 & 0.3120 & Valid \\
\hline
\end{tabular}

Soiuce: primary data of SPSS (2019)

The employee performance variable consists of 5 statement items. The correlation of each statement item has a value of $r$ count greater than $r$ table, so based on the validity test it shows that all statement items on the employee performance variable are declared valid and can be used as a research instrument.

\section{Test Reliabilitas}

To test the reliability (reliability) of a statement used the Cronbach's Alpha analysis technique for each research variable through the SPSS program. The results of this test can 
be said to be reliable if Cronbach's Alpha is $>0.6$ (Malhotra, 2012: 289). The results of the reliability test of the variables under study can be seen in the table below:

Tabel 4.8

Reliability Test

\begin{tabular}{|c|c|c|c|}
\hline Variabel & Cronbach's Alpha & Criteria & Statement \\
\hline Work experience $\left(\mathrm{X}_{1}\right)$ & 0.758 & 0.6 & Reliabel \\
\hline Motivation $\left(\mathrm{X}_{2}\right)$ & 0.630 & 0.6 & Reliabel \\
\hline competence $\left(\mathrm{X}_{3}\right)$ & 0.629 & 0.6 & Reliabel \\
\hline Performance $(\mathrm{Y})$ & 0.637 & 0.6 & Reliabel \\
\hline
\end{tabular}

Source: primary data by SPSS (2019)

Based on table 4.8 it is known that the Cronbach's Alpha value of the work experience variable (X1), motivation (X2), competence (X3) and employee performance (Y) is greater than 0.6 so it can be concluded that the data is reliable, which means that the questionnaire can be used in the study.

\section{Gauss Markov Test \\ Normality Test}


The normality test aims to test whether in the regression model confounding or residual variables have a normal distribution. To be able to test the normality of the regression model, this study uses the Normal P-P Plot of Regression Standardized Residual method.

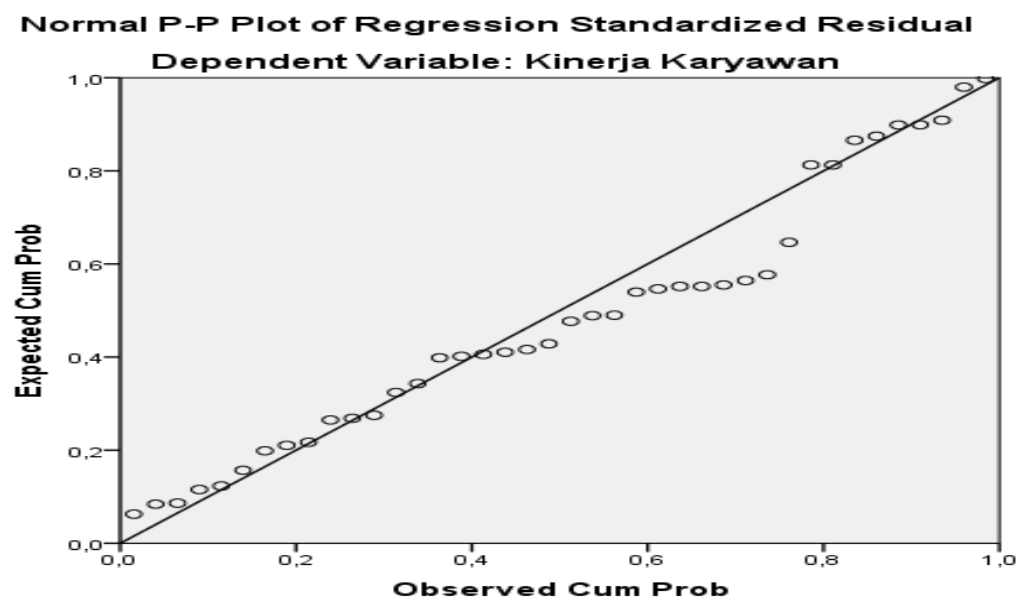

The basis for decision making is if the data spreads far from the diagonal line or does not follow the direction of the diagonal line, then the regression model does not meet the assumption of normality.

\section{Normal P-P Plot of Regression Standardized Residual}

Source : primary data by SPSS (2019)

Besides using a graphical test equipped with statistical tests, one of which is by using the Kolmogorof-Smirnov non-parametic statistical test. If the K-S result has a $\mathrm{p}$ value $>0.05$, it can be said that the unstandardized residual is normal. The test results are presented in the following table:

Tabel 4.9

Normality Test Results 


\section{One-Sample Kolmogorov-Smirnov Test}

\begin{tabular}{|ll|r|}
\hline & & \multicolumn{2}{|c|}{$\begin{array}{c}\text { Unstandardized } \\
\text { Residual }\end{array}$} \\
\hline $\mathrm{N}$ & & 40 \\
Normal Parameters ${ }^{\mathrm{a}, \mathrm{b}}$ & Mean &, 0000000 \\
& Std. Deviation &, 84488434 \\
Most Extreme Differences & Absolute &, 170 \\
& Positive &, 170 \\
Kolmogorov-Smirnov Z & Negative &,- 055 \\
Asymp. Sig. (2-tailed) & & 1,076 \\
\end{tabular}

a. Test distribution is Normal.

b. Calculated from data.

\section{Test Heteroskedastisitas}

The heteroscedasticity test aims to detect the occurrence of different relevant values from each variant of the independent variables, namely work experience (X1), motivation (X2), competence (X3) in the regression model.

\section{Uji Heteroskedastisitas}

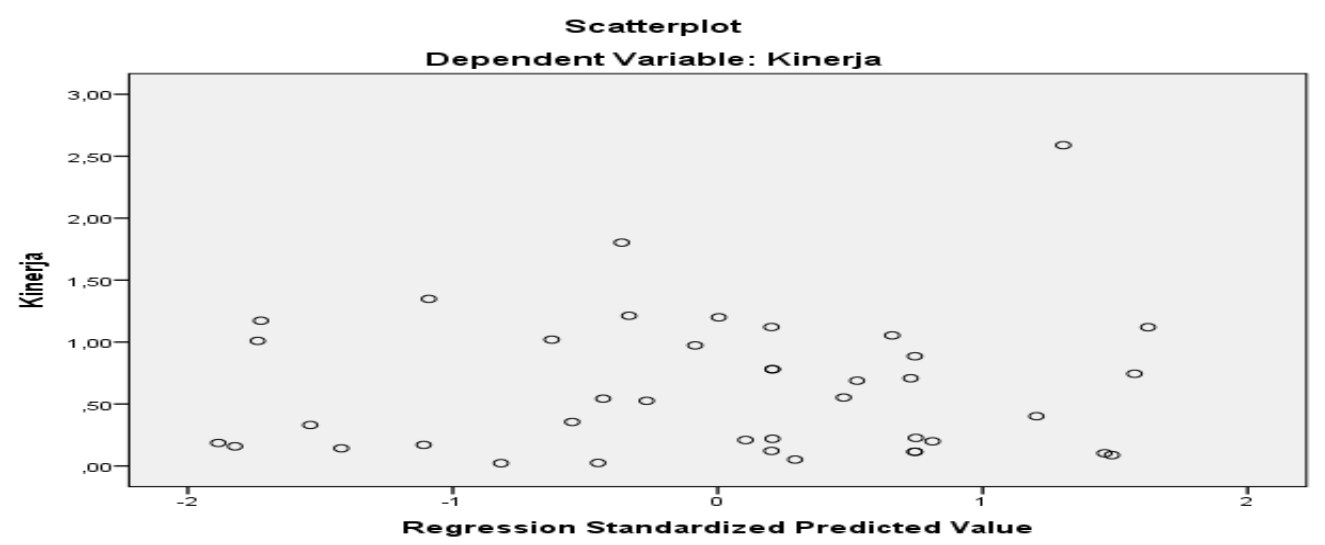

Sumber: data primer diola dengan SPSS (2019)

In Figure 4.2, the results of the heteroscedasticity test in the image above show that the scatterplot does not form a certain pattern and the point spreads above and below the number 0 on the $\mathrm{Y}$ axis, so there is no heteroscedasticity.

\section{Mutiple linear regression analysis}


Regression analysis is used to determine the extent of the relationship between the independent variables and the dependent variable. Based on the regression analysis using SPSS, the following results were obtained:

Tabel 4.10

Coefficients $^{\mathrm{a}}$

\begin{tabular}{|c|c|c|c|c|c|c|}
\hline \multirow{2}{*}{\multicolumn{2}{|c|}{ Model }} & \multicolumn{2}{|c|}{$\begin{array}{c}\text { Unstandardized } \\
\text { Coefficients }\end{array}$} & \multirow{2}{*}{$\begin{array}{l}\text { Standardized } \\
\text { Coefficients }\end{array}$} & \multirow[t]{2}{*}{$\mathrm{T}$} & \multirow[t]{2}{*}{ Sig. } \\
\hline & & B & Std. Error & & & \\
\hline \multirow{5}{*}{1} & (Constant) & 4,402 & 2,530 & & 1,740 & ,090 \\
\hline & Prestasi &,- 168 & ,075 &,- 163 & $-2,246$ & ,031 \\
\hline & Kerja & & & & & \\
\hline & Motivasi &, 825 &, 067 & ,897 & 12,342 &, 000 \\
\hline & Kompetensi & , 158 & 077 &, 150 & 2,058 &, 047 \\
\hline
\end{tabular}

a. Dependent Variable: Kinerja Karyawan

Sumber: data primer diolah dengan SPSS (2019)

$$
Y=4.402+(-0.168) X_{1}+0.825 X_{2}+0.158 X_{3}+e
$$

\section{Test Multikolinieritas}

Multicollinearity test was used to test whether the regression model found any correlation between the independent variables, namely work experience (X1), motivation (X2), competence (X3). Multicollinearity can be seen from the Tolerance and Variance Invlation Factor (VIF) values. If the Tolerance value $<0.1$ or Variance Invlation Factor (VIF) $>10$, multicollinearity occurs. If the Tolerance value $>0.1$ and the Variance Invlation Factor (VIF) value $<10$, multicollinearity does not occur.

Tabel 4.11

Multikolinieritas Test Result 


\section{Coefficients $^{\mathrm{a}}$}

\begin{tabular}{|c|c|c|c|}
\hline \multicolumn{2}{|c|}{ Model } & \multicolumn{2}{|c|}{ Collinearity Statistics } \\
\hline & & Tolerance & VIF \\
\hline \multirow{3}{*}{1} & Work Performance & ,990 & 1,010 \\
\hline & Motivation & ,990 & 1,010 \\
\hline & Competence & ,989 & 1,011 \\
\hline
\end{tabular}

a. Dependent Variable: Kinerja Karyawan

Source : SPSS result (2019)

Based on the table 4.10 above, the tolerance value for all variables is more than 0.1 and the variance inflation factor (VIF) value is less than 10 . So it can be concluded that the data of this study does not experience multicollinearity between independent variables.

\section{Test Hipotesis}

\subsubsection{Test F (Simultan)}

This test is used to determine whether the independent variables in this case work experience (X1), motivation (X2), competence (X3) together (simultaneously) have a significant effect on the dependent variable, namely employee performance $(\mathrm{Y})$.

Tabel 4.12

\section{F Test Result (Simultaneous)}

ANOVA ${ }^{a}$

\begin{tabular}{|rl|r|r|r|r|r|}
\hline Model & & Sum of Squares & Df & Mean Square & F & Sig. \\
\hline \multirow{2}{*}{1} & Regression & 120,136 & 3 & 40,045 & 51,784 &, $000^{\mathrm{b}}$ \\
& Residual & 27,839 & 36 &, 773 & & \\
& Total & 147,975 & 39 & & & \\
\hline
\end{tabular}

a. Dependent Variable: Kinerja Karyawan

b. Predictors: (Constant), Kompetensi, Motivasi, Prestasi Kerja

Sumber: Hasill Output SPSS (2019)

\subsubsection{Test $\mathrm{t}$ (Parsial)}


The $t$ statistical test is basically used to show how far the influence of one explanatory / independent variable individually in explaining the dependent variation. From the results of processing data through the SPSS program, the following table is obtained:

Tabel 4.13

Parsial t test

Coefficients $^{\mathrm{a}}$

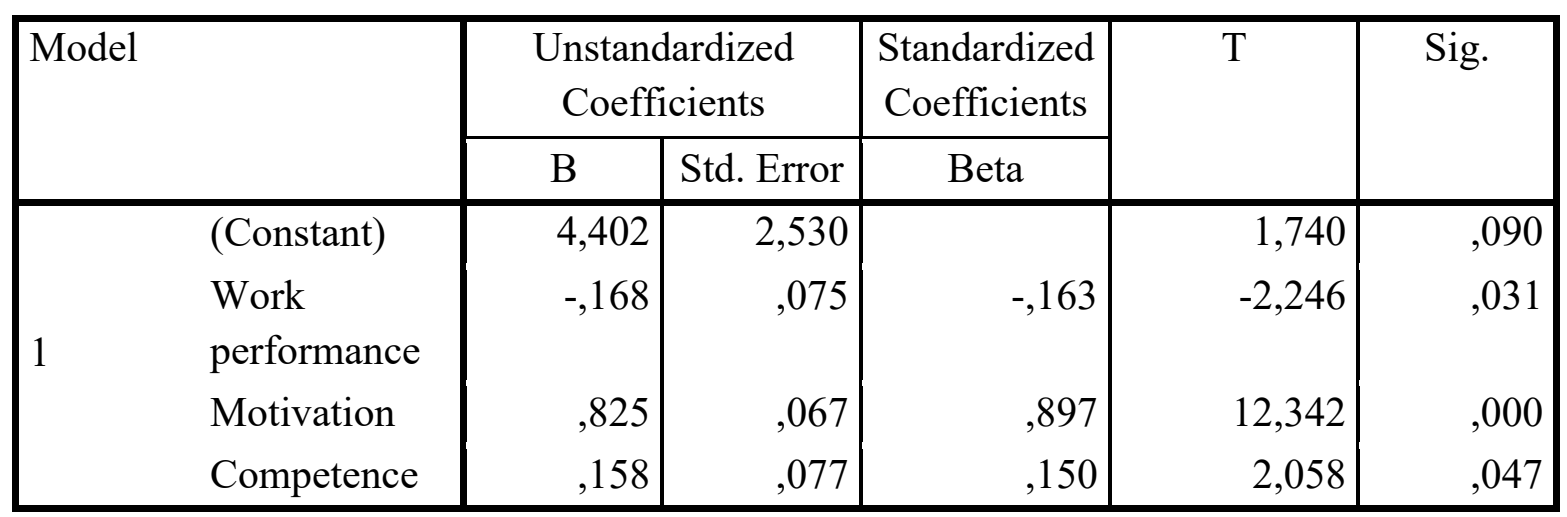

\subsection{Multiple Determination Coefficient Analysis}

Measurement of the multiple coefficient of determination aims to determine the magnitude of the correlation and relationship between variables of the regression model in this study and to measure how close the estimated regression lines are to the actual data. This can be seen from the R and R2 coefficients. The results of measuring the multiple correlation coefficient in this study can be seen in the following table

\section{Result Test of Koefisiensi $R$ and $\mathbf{R}^{2}$}

Tabel 4.14

Model Summary

\begin{tabular}{|l|r|r|r|r|}
\hline Model & \multicolumn{1}{|c|}{$\mathrm{R}$} & \multicolumn{1}{|c|}{ R Square } & Adjusted R Square & \multicolumn{2}{|c|}{$\begin{array}{c}\text { Std. Error of the } \\
\text { Estimate }\end{array}$} \\
\hline 1 &, $901^{\mathrm{a}}$ &, 812 &, 796 &, 879 \\
\hline
\end{tabular}

a. Predictors: (Constant), Kompetensi, Motivasi, Prestasi Kerja

b. Dependent Variable: Kinerja Karyawan

Source : SPSS results (2019)

From the table 4.13 above, it is known that the coefficient of multiple determination $\mathrm{R}$ Square is 0.812 or $81.2 \%$. This value shows that employee performance is influenced by 
the variable $\mathrm{p}$ work experience $(\mathrm{X} 1)$, motivation $(\mathrm{X} 2)$, competence $(\mathrm{X} 3)$, the remaining $18.8 \%$ is influenced by other variables not examined in this study.

\section{DISCUSSION}

Based on the results of statistical testing, it can be seen simultaneously that all dependent variables, namely work experience, motivation and competence have a positive and significant effect on employee performance.

\section{Partial effect of work experience on employee performance}

Work experience (X1) has a $t$ value of $(-2.246)$, this value is greater than the table (2.02108) and sig $\mathrm{t}(0.031)$ is less than $5 \% \mathrm{~b}(0.05)$. So that the research hypothesis testing for $\mathrm{HO}$ is rejected and $\mathrm{H} 1$ is accepted. This explains that partially the work experience variable (X1) has a significant effect on employee performance (Y). The reason can be seen in the questionnaire submitted to the majority of respondents who answered agree, as in statements two and four of the respondents' answers were very high.

\section{The influence of motivation partially on employee performance}

Motivation (X2) has a $t$ value of 12.342. This value is greater than $t$ table (2.02108) and sig $\mathrm{t}(0.000)$ less than $5 \%(0.05)$. So that the research hypothesis testing for HO is rejected and $\mathrm{H} 1$ is accepted. This explains that partially the motivation variable (X2) has a significant effect on employee performance (Y). The reason can be seen in the questionnaire proposed to the respondents that the majority of the several statement items answered agree.

\section{Partial influence of competence on employee performance}

Competence (X3) has a t value of 2.058. This value is greater than t table (2.03951) and $\operatorname{sig} \mathrm{t}(0.047)$ is less than $5 \%(0.05)$. So that the research hypothesis testing for $\mathrm{HO}$ is rejected and $\mathrm{H} 1$ is accepted. This explains that partially the motivation variable (X3) has a significant effect on employee performance (Y). The reason can be seen in the

questionnaire submitted to the respondent that the majority of the several statement items answered agree,

\section{The effect of work experience,motivation and competence simultaneously on employee performance.}

Based on the SPSS output, the results of the research in the fourth equation show that there is a positive and significant effect simultaneously (simultaneously) between work experience, motivation and competence on the performance of employees of Mee Macau Surabaya. The reason can be seen in the responses of respondents, where the majority of 
respondents agree with the statements obtained in the questionnaire proposed and are indicators of work experience, motivation and competence on employee performance, it will increase perspectives that lead to positive results which will affect employee performance. This means that the better the work experience, motivation and competence the employees have, the better the employee's performance will be. And vice versa.

\section{CONCLUSION}

Based on the results of research with quantitative methods, the researchers can conclude as follows:

$>$ From the results of the partial test conducted on the first hypothesis, it can be concluded that the work experience variable (X1) has a positive and significant effect on the employee performance variable (Y) Mee Macau Surabaya. This means that the better the work experience that the employee has, the better the performance that the employee will display.

$>$ From the results of the partial test conducted on the second hypothesis, it can be concluded that the motivation variable (X2) has a positive and significant effect on the employee performance variable (Y) Mee Macau Surabaya. This means that the better the employee's motivation, the better the employee's performance will be.

$>$ From the results of the partial test conducted on the third hypothesis, it can be concluded that the competency variable (X3) has a positive and significant effect on the employee performance variable (Y) Mee Macau Surabaya. This means that the better the competencies possessed by employees, the better the performance displayed by the employees.

From the results of simultaneous tests carried out by the three variables studied, namely work experience (X1), motivation (X2), and competence (X3), together (simultaneously) have a significant effect on employee performance (Y) Mee Macau Surabaya. This means that the better work experience, motivation and competence displayed by employees will also be better.

\section{SUGGESTION}

Based on the results of research on work experience, motivation and competence on employee performance as a consideration for the company and further research, among others:

1. The company is expected to be able to maintain what has been given to employees as existing facilities or regulations. Because the existing facilities affect how many employees work and so do the existing regulations. For facilities for employees, you can pay attention. 
2. For researchers who will conduct further research, it is hoped that this research can be used as a reference, support, guidelines, comparison, and it is hoped that to add other variables that can be used as indicators in further research. This is because there are still variables that researchers have not found that still have a relationship related to employee performance.

3. Research also provides evidence that work experience, motivation and competence factors together have a positive and significant effect so that employees who have good performance can be found.

\section{REFRENCES}




\section{Book literature :}

Hani, Handoko T, "Manajemen Personalia dan Sumber daya Manusia”,BPFE,Yogyakarta,2008

A.A. Anwar Prabu Mangkunegara. (2011). Manajemen Sumber Daya Manusia Perusahaan. Bandung : Rosda

Fahmi, Irham. (2012). "Manajemen Kepemimpinan Teori dan Aplikasi". Bandung: Alfabeta, cv.

Hasibuan, Malayu S.P. (2011). "Manajemen Sumber Daya Manusia” .Jakarta:

Penerbit Bumi Aksara.

Sugiyono. (2014). “Metode Penelitian Manajemen”.Bandung: Penerbit Alfabeta.

Wibowo. (2012). “Manajemen Kinerja”. Jakarta: PT. Raja Grafindo Persada.

Foster, Bill. 2010. Pembinaan untuk Peningkatan Kinerja Karyawan.PPM : Jakarta.

Robbins, P. Stephen. (2013) Perilaku Organisasi . Edisi Sembilan, Jilid 2. Edisi Bahasa Indonesia. PT Indeks Kelompok Gramedia, Jakrta.

Siagian, P. Sondang. (2013). Manajemen Sumber Daya Manusia. Edisi Satu. PT Bumi Aksara, Jakarta.

Sugiyono. (2010). Metode Penelitian Kualitatif Kuantitatif. Bandung: Alfabeta.

Suparno, \& Sudarwati. (2014). Pengaruh Motivasi Displin Kerja Dan Kompetensi

Terhadap Kinerja Karyawan Dinas Pendidikan Sragen. Jurnal Paradigma Vol. 12 ISSN : 1693-0827.

Edy Sutrisno. 2014. Manajemen Sumber Daya Manusia. Cetak Ke Enam. Pranada Media Group, Jakarta.

Sugiyono, 2013. Metode Penelitian Kuantitatif, Kualitatif, dan R\&B, Penerbit Alfabeta, Bandung.

Malayu Hasibuan, S. P, 2013. Manajemen Sumber Daya Manusia. Edisi REvisi PT. Bumi Aksara, Jakarta. 